The public institutions say that they are not alarmed by these questions; almost all of those that are validating the private-college programs generate useful income from the exercise and are based outside London. They are thus enabling their own degrees to be offered by the colleges in the London market to a range of students who would probably never come to their own campus. From the national perspective the emergence of this private-sector alternative is broadening the United Kingdom's offer to international students; more of them will come to the United Kingdom as a result.

The report makes several policy recommendations that the new UK government will be considering. Some of these relate to tidying up the regulatory framework, which is confused and incomplete; others suggest that it is time for the private sector to be brought into policy discussions and for it to provide comprehensive information on its activities. Some big questions and opportunities remain. A cash-strapped government might well be tempted to make a contract with private colleges to teach UK students for a price below what they currently pay for the publicly funded institutions; it is also possible that other US providers could follow the Apollo Group and enter the UK market. In any event the coming years are sure to see a continuing growth in private provision for both domestic and international students.

\section{India's Open Door to Foreign Universities: Less Than Meets the Eye}

\section{Philip G. Altbach}

Philip G. Altbach is Monan University Professor and director of the Center for International Higher Education at Boston College.

$\mathrm{I}^{\mathrm{s}-1}$ ndia may finally open its doors to foreign higher education 1 institutions and investment. The cabinet has approved human resource development minister Kapil Sibal's proposed law, and it will be voted in Parliament in the near future. Indian comment has been largely favorable. What will an open door mean for Indian higher education - and to foreign institutions that may be interested in setting up shop in India? Basically, the result is likely less than is currently being envisaged, and there will be problems of implementation and of result as well.

\section{The Political and Educational Context}

Everyone recognizes that India has a serious higher education problem. Although India's higher education system, with more than I3 million students, is the world's third largest, it only educates around I2 percent of the age group, well under China's 27 percent and half or more in middle-income countries. Thus, it is a challenge of providing access to India's expanding population of young people and rapidly growing

Everyone recognizes that India has a serious higher education problem.

middle class. India also faces a serious quality problem - given that only a tiny proportion of the higher education sector can meet international standards. The justly famous Indian Institutes of Technology and the Institutes of Management constitute a tiny elite, as well as a few specialized schools such as the Tata Institute of Fundamental Research, one or two private institutions such as the Birla Institute of Technology and Science, and perhaps too top-rated undergraduate colleges. Almost all of India's 480 public universities and more than 25,000 undergraduate colleges are, by international standards, mediocre at best. India's complex legal arrangements for reserving places in higher education to members of various disadvantaged population groups, often setting aside up to half of the seats for such groups, places further stress on the system.

\section{A Capacity Problem}

India faces severe problems of capacity in its entire educational system in part because of underinvestment over many decades. More than a third of Indians remain illiterate after more than a half century of independence. On April I, a new law took effect that makes primary education free and compulsory. While admirable, it takes place in a context of scarcity of trained teachers, inadequate budgets, and shoddy supervision. Minister Sibal has been shaking up the higher education establishment as well. The University Grants Commission and the All-India Council for Technical Education, responsible respectively for supervising the universities and the technical institutions, are being abolished and replaced with a new combined entity. But no one knows just how the new organization will work or who will staff it. India's higher education accrediting and quality assurance organization, the National Assessment and Accreditation Council, which was well-known for its slow movement, is being shaken up. But, again, it is unclear what will take its place or how it might be changed.

Current plans include the establishing of new national "world-class" universities in each of India's states, opening new IITs, and other initiatives. These plans, given the inadequate funds that have been announced and the shortage of qualified professors, are unlikely to succeed. The fact is that 
academic salaries do not compare favorably with remuneration offered by India's growing private sector and are uncompetitive by international standards. Many of India's top academics are teaching in the United States, Britain, and elsewhere. Even Ethiopia and Eritrea recruit Indian academics.

This lack of capacity will affect India's new open-door policy. If India does open its door to foreign institutions, it will be unable to adequately regulate and evaluate them.

\section{Why Welcome the Foreigners?}

Minister Sibal seems to have several goals for permitting foreign universities to enter the Indian market. The foreigners are expected to provide much needed capacity and new ideas about higher education management, curriculum, teaching methods, and research. It is hoped that they will bring investment. Top-class foreign universities are anticipated to add prestige to India's postsecondary system. All of these assumptions are at the very least questionable. While foreign transplants elsewhere in the world have provided some additional access, they have not dramatically increased student numbers. Almost all branch campuses are small and limited in scope and field. In the Persian Gulf, Vietnam, and Malaysia, where foreign branch campuses have been active, student access has been only modestly affected by them. Branch campuses are typically fairly small and almost always specialized in fields that are inexpen-

\section{Current plans include the establishing of new national "world-class" universities in each of India's states, opening new IITs, and other initiatives.}

sive to offer and have a ready clientele such as business studies, technology, and hospitality management. Few branch campuses bring much in the way of academic innovation. Typically, they use tried and true management, curriculum, and teaching methods. The branches frequently have little autonomy from their home university and are, thus, tightly controlled from abroad. While some of the ideas brought to India may be useful, not much can be expected.

Foreign providers will bring some investment to the higher education sector, particularly since the new law requires an investment of a minimum of \$II million-a kind of entry fee-but the total amount brought into India is unlikely to be quite large. Experience shows that sponsoring universities abroad seldom spend significant amounts on their branchesmajor investment often comes from the host countries such as the oil-rich Gulf states. It is likely that the foreigners will be interested in "testing the waters" in India to see if their initiatives will be sustainable, and thus are likely to want to limit their initial investments.

Global experience shows that the large majority of higher education institutions entering a foreign market are not pres- tigious universities but rather low-end institutions seeking market access and income. The new for-profit sector is especially interested in global expansion as well. Top universities may well establish collaborative arrangement with Indian peer institutions or study/research centers in India, but are unlikely to build full-fledged branch campuses on their own. There may be a few exceptions, such as the Georgia Institute of Technology, which is apparently thinking of a major investment in Hyderabad.

At least in the immediate and midterm future, it is quite unlikely that foreign initiatives will do what the Indian authorities hope they will accomplish.

Global experience shows that the large majority of higher education institutions entering a foreign market are not prestigious universities but rather low-end institutions seeking market access and income.

\section{The Half-Open Door}

India's open door comes with a variety of conditions and limitations. It might better be called the "half-open door." These conditions may well deter many foreign institutions from involvement in India. The proposed legislation requires an investment of \$II million up front by a foreign provider in the India operation. Moreover, the foreign provider is restricted from making any profit on the Indian branch.

It is not clear if Indian authorities will evaluate a foreign institution before permission is given to set up a branch campus or another initiative-or if so, who will do the vetting. It is not clear if the foreign branches will be subject to India's highly complicated and controversial reservations regime (affirmative action programs) that often stipulates that half of enrollments consist of designated disadvantaged sections of the population. If the foreigners are required to admit large numbers of students from low-income families who are unlikely to afford high foreign campus fees and often require costly remedial preparation, creating financially stable branches may be close to impossible.

A further possible complication may be the role of state governments in setting their own regulations and conditions for foreign branches. Indian education is a joint responsibility of the central and state governments, and many of the states have differing approaches to higher education generally and to foreign involvement in particular. Some, such as Andhra Pradesh and Karnataka in the south, have been quite interested. Other states-such as West Bengal with its communist government, may be more skeptical. And a few, such as Chattisgarh, have been known to sell access to university status to the highest bidders. 
Foreign institutions will need to deal with India's often impenetrable and sometimes corrupt bureaucracy. For example, recent reports have evidence that some Indian institutions were granted a coveted "deemed" university status after questionable practices between the applicants and high government officials. It is unclear if the foreign branches will be evaluated by Indian authorities or if overseas quality-assurance and accrediting agencies will be fully involved.

In short, many unanswered questions remain concerning just how foreigners will be admitted to India, how they will be managed, and who will control a highly complex set of relationships.

\section{A Likely SCEnARIO}

India's higher education needs are significant. The country needs more enrollment capacity at the bottom of the system as well as more places at its small elite sector at the top. The system needs systemic reform. Furthermore, fresh breezes from abroad might help to galvanize local thinking. Yet, it is impossible for foreigners to solve or even to make a visible dent in India's higher education system.

Foreign institutions, once they realize the challenges of the Indian environment are unlikely to jump in a big way. Some may wish to test the waters. Many others will be deterred by the conditions put into place by Indian authorities and the uncertainties of the local situation.

The involvement of foreign higher education providers in India is perhaps just as murky as it was prior to Minister Sibal's new regime.

(This article also appears in the Chronicle of Higher Education.)

\section{Legal Frameworks for Higher Education in Sub-Saharan}

\section{Africa}

\section{William Saint}

William Saint is a higher education consultant specializing in sub-Saharan Africa. E-mail: wsaint@cox.net. Some of the themes discussed in this article are in the author's article, "Legal Frameworks for Higher Education Governance in Sub-Saharan Africa," Higher Education Policy, vol. 22 (no. 4), 2009 .

A shortage of research on the legal frameworks for higher education is evident in sub-Saharan Africa. Out of 49 countries, half either have no legal framework at all or one at least two decades old. Consequently, the national higher education legislation and individual statutes of public universities in 24 sub-Saharan African countries were analyzed and compared.

\section{As sub-Saharan African higher education has} swelled, many governments have established intermediary-or "buffer"-bodies to oversee their increasingly complex systems.

\section{System Governance}

As sub-Saharan African higher education has swelled, many governments have established intermediary-or "buffer"bodies to oversee their increasingly complex systems. Such boards are more commonly found in English-speaking countries. French-speaking countries have tended to create separate ministries of higher education. Presently, I5 of 42 countries possess semiautonomous buffer bodies. The number of members on their governing boards ranges from 7 to 28 , with an average of $\mathrm{I} 6$. Composition often reflects a balance among public sector, academic community, and private-sector representatives.

In a majority of countries, board appointments are made directly by the head of state, prime minister, or minister of education. In other cases, a blended procedure is followed, whereby some members are appointed and others are elected democratically from within legally designated stakeholder groups.

\section{INSTITUTIONAL GovernANCE}

Universities are characterized by similar governance structures. Usually, a governing board is charged with formulating the institution's strategic direction, approving internal statutes, accepting budgets, accounting for use of funds, managing the institution's assets, and safeguarding institutional interests. The first model, characteristic of French- and Portuguesespeaking universities, is made up entirely or largely of university staff and student representatives. Chaired by the chief officer, it governs with considerable autonomy and little involvement of external stakeholders. This model gives considerable authority to the chief officer. The second model, found in English-speaking universities, incorporates various types of external members within the board. Most common are government representatives, followed by those from the private sector.

\section{Governing BoARdS}

The number of university board members ranges from a low of II to a high of more than 40. Recent reforms accord with international trends toward smaller boards and a larger portion of external stakeholders. Procedures used in appointing board members provide insight into the lines of political accountabil- 